\title{
FREE TRADE AGREEMENT: IMPACTS ON THE COSTA RICAN DAIRY MARKET
}

\author{
Víctor Rodriguez-Lizano¹, Mercedes Montero-Vega², Javier Paniagua-Molina ${ }^{3}$
}

${ }^{123}$ Agricultural Economics and Agribusiness Development Research Center (CIEDA), Department of Agricultural Economics,
University of Costa Rica
Email: ${ }^{1}$ victorantonio.rodriguez@ucr.ac.cr(corresponding author), ${ }^{2}$ mercedes.montero@ucr.ac.cr, ${ }^{3}$ javier.paniagua@ucr.ac.cr

\begin{abstract}
According to the Free Trade Agreement with Central America, Dominican Republic and United States signed in 2008, milk import tariff reliefs will stagger down from 59,4\% to 0\% by 2025. This study determined milk demand and supply curves in the Costa Rican domestic market. Several variables and two different models were conducted to estimate milk demand and supply: Ordinary Least Squares and Two Stages Least Square simultaneous equations. In both cases, demand was estimated by income and milk prices as independent variables; while supply was estimated by input and milk prices. Nonetheless, the best fit was obtained by TSLS model because it accounts for endogeneity among price and quantity. Based on this model, if domestic prices are supposed to decrease due to increasing quantities of imported lower-priced milk, then national demand would increase (9\% average) and national production is expected to decrease (26\% average). The gap between national milk demand and supply is expected to be filled by milk imported from United States; assuming 0\% tariff, no transaction costs and constant share of exports within national production.
\end{abstract}

Keywords: Milk Market, Costa Rica, Free Trade Agreement

(JEL Classification: F1, Q17)

\section{Introduction}

The agricultural sector in Costa Rica is the only one in which the country has had a historical positive balance of trade (Procomer, 2016), which has increasing since 2010. In 2008, Costa Rica signed the Free Trade Agreement with Central America, Dominican Republic and United States (DR-CAFTA); however, how the DR-CAFTA may affect the consumption and production patterns of national agricultural products is not clear, since there are no estimations on future economic changes of this free trade agreement.

Although fluid milk was included in the DR-CAFTA, the impact it would eventually have on the national market has not been estimated. Fluid milk used to have a $59.4 \%$ tariff and according to the DR-CAFTA's conditions, this tariff would stagger down until its total elimination in 2025. Costa Rica has signed several free trade agreements with different countries, including Chile, China, Canada, Singapore, Panama, European Union and Mexico; however, this research is motivated exclusively by the tariff-rate reduction established by the DR-CAFTA, since United States (US) is among the largest dairy producer worldwide. The five largest milk producers in the base period are the European Union with a share in global production of 20\%; India at 19\%; the United States at 12\%; and China and Pakistan, both at 5\%.

The structure of Costa Rican dairy production is widely distributed among many small farmers; however, industrialization is more concentrated in few larger companies, especially by a farmers' cooperative, named Dos Pinos, which is the most important dairy company in the country with $85 \%$ of fluid milk market share and $63.9 \%$ of dairy products (Euromonitor, 2018) and $88 \%$ of retail sales value (Euromonitor, 2015). Production-wise, Costa Rica has a large proportion of small dairy farms since $48 \%$ of them are small (INEC, 2014) by national standards i.e. less than 15 cows (INEC, 2014). Therefore, tariff reliefs are expected to impact a large proportion of the small-scale farmers (Rodríguez and Montero, 2016).

The abovementioned cooperative, as well as other companies have a wide range of dairy products; yet, 70,9\% of drinking milk products is fluid milk (Euromonitor, 2018). Regarding international market, Costa Rican exports have increased in the past years, especially to Central America; the value of exports increased from 2011 to 2015 in $45.6 \%$ (TICA, 2015); in which fluid milk represent $61 \%$ of exports (TICA, 2015).

In terms of competitiveness, while The Global Competitiveness Index ranked Costa Rica in the 52nd position from 140 countries, the United Sates is ranked in the 3rd position (World Economic Forum, 2016). Currently, the US dairy market is one of the strongest worldwide, exporting $6 \%$ of the World's butter, $14 \%$ of cheese, and $26 \%$ skim milk powder (OECD/FAO, 2016). On the other hand, the strengthening of both the US Dollar and the Euro is expected to put pressure on the growth of exports of these regions, as 
their competitiveness is threatened by their strong currencies (OECD/FAO, 2016).

The above-mentioned situation places Costa Rican dairy market in an uncertain position regarding dairy trade with US, since there are no previous studies and the results of the tariff relief for the local market are yet unknown. Since there are no estimates, our main goal is to contribute by providing a model which can explain demand and supply behaviour by analysing how the DR-CAFTA would affect the consumption and production of fluid milk within Costa Rican economy.

\section{LITERATURE REVIEW}

The following section describes the main methods used in agriculture and dairy production systems to model changes in demand and supply. Consequently, the following literature review includes similar research related to the agricultural sector, especially milk or dairy production but does not intend to be a comprehensive overview of modelling in agriculture. A summary of similar researched topics and their corresponding methods can be observed in table 1 .

Modelling the diverse effects of agricultural trade has been heavily documented. Hinojosa-Ojeda et al. (1995) modelled trough a Computable General Equilibrium (CGE) how the potential costs and benefits of supply chain integration can be distributed among countries, sectors, and social classes for the North American Free Trade Agreement (NAFTA) between US, Mexico, Central America and the Caribbean. This model consists of 11 sectors, four social groups, and four sub-regions (plus the rest of the world), linked though trade, capital, and migration flows; main results are targeted towards policy strategies to convey in optimal outcomes for the region.

Shepherd (2006) used the Kalman Filter algorithm to estimate a structural time series model for cotton supply for 30 countries and 16 regions. This research focuses on the impact of different policy measures. Results demonstrated countries differ significantly in their supply responsiveness to world price changes and therefore parameters for analysis need to be adjusted correspondingly. Since variables need to be country-specific it may reduce cross-country comparability when dealing with a mixture of stationary and non-stationary models.

Regarding the dairy and milk market, Davis et al. (2009) used a trans-log demand system, a censored demand system and Almost Ideal Demand System (AIDS) model to analyse consumption of different fluid milk products. This research considered home consumption and preferences of whole milk, whole flavoured milk, reduced fat milk, flavoured reduced fat milk, buttermilk, canned milk, and all other fluid milk products. Main results demonstrated show how price and consumers' income are the main drivers of consumption. Hannan et al. (2010) used a variation of the AIDS model to determine the impacts of per capita total expenditure, food prices and demographic variables on household demand for dairy products in Bangladesh. The research collected data of 7440 households and analysed expenditures meat, eggs, milk, butter, ghee, cards, sweets and tea and coffee from which price and income elasticities were estimated.

Ramirez Jaspeado et al. (2010) used a Two-Stage Least Square (TSLS) model considering demand, supply, prices and imports to estimate the effects of the US-Mexican free trade agreement in the milk market. Variables used in this model were: milk quantity, price paid to milk producers, sorghum and alfalfa-bean prices (and their respective lags), industry price of milk, international powder milk price, real retail milk price, quantity demanded of milk, maximum milk price (retail), refreshment real average price, banana and bread prices. Changes in world market prices do not reflect on changes in the Mexican market because of protectionist policies in the dairy market. Protectionist policies are responsible for the lack of explanatory power of the variables in this case $\left(\mathrm{R}^{\wedge} 2=0.35\right)$. On the other hand, during 1994-2005, results showed the free trade agreement had positive effects on milk production because of the reduction of agricultural input prices; these are sorghum and alfalfa prices, reducing the negative effect of low worldwide milk prices for Mexican dairy farmers. In regards of refreshment and milk crossed elasticities, an inelastic response of milk was obtained from changes in refreshment prices.

Regarding technical efficiency Zhu et al. (2012) analysed Dutch, German and Swedish farms between 1995 to 2004 and developed a trans-log model for determining efficiency of farm production. Independent variables used were: subsidies, farm size, degree of specialization regarding milk production, family labour, rented land, long and short- term debt and time trend. Results suggest that the motivation of farmers to work efficiently is lower when they depend to a higher degree on subsidies as a source of income. Results indicate that the composition of subsidies have a much smaller effect on efficiency than the composition of total farm income does. Subsidies were one of the main aspects evaluated in this research and although they are not part of Costa Rican agriculture, the effects these may have in the behaviour of European farmers can affect the milk market in smaller countries.

Considering the incorporation of environmental variables into sustainable development, Mukherjee et al. (2012) adopted panel data of a Stochastic Production Frontier (SPF) to measure technical efficiency. Variables used in the model were: milk sold by farm, number of dairy cows, feed use, full time equivalent workers, capital flow, time trends, technological changes and heat stress indexes.

The specific DR-CAFTA and milk sector was analysed by Huang and Durón-Benítez (2015). Cheese, fluid milk and powdered milk demand was estimated using the generalized least square (GLS). Elasticity estimates, showed that cheese was considered an inferior good in Costa Rica, also, demand was significantly affected by import prices of milk in El Salvador and by powdered milk in Costa Rica. Cheese and fluid milk were income and price inelastic in most countries. Also, cheese and fluid milk import prices were elastic, however powdered milk was inelastic. Substitution effects suggest that increases in imported fluid milk prices would increase the demand for powdered milk. 
Muluwork-Atsbeha et al. (2016) analysed the pricemodelling scheme of milk based on its components (protein, fat and lactose). In this case the modelling scheme used was symmetric normalized quadratic (SNQ) functional form under a quota regime. For this research, 261 farms were used from estimation from which 1127 observations were considered for 4.3 years. A model for milk component supply was estimated under a profit maximizing dairy farm assumption in a tradable quota regime. As expected, price incentives affect milk composition in the short run and component supplies respond accordingly to price changes. Results suggest policy must allow for flexibility to make sure dairy production can respond to changes in component demand.

Table 1. Summary of literature review on methods used in agricultural modelling

\begin{tabular}{lll}
\hline Author & Method(s) used & Topic \\
\hline & $\begin{array}{l}\text { Translog demand sys- } \\
\text { tem, censored demand } \\
\text { system, AIDS }\end{array}$ & $\begin{array}{l}\text { Milk and dairy } \\
\text { products }\end{array}$ \\
(Davis et al., 2009) &
\end{tabular}

(Ramirez Jaspeado et Two stage least square al. 2010) method

Milk and dairy products + Free Trade Agreement

Structural time-series Theoretical model of component supply (Shepherd 2006) under tradable quota (Muluwork-Atsbeha et al. 2016) regime by the symmetric normalized quadratic (SNQ) functional form

A double-log model. Two types of demand:

(Huang and DurónBenítez 2015)

(Mukherjee et al. 2012)

(Hannan et al. 2010)

A variation of the Almost Ideal Demand System (AIDS)

(Hinojosa-Ojeda et al Multi-regional CGE 1995) framework.

Translog specification of the output distance

(Zhu et al. 2012)

Cotton
Milk

Cheese and fluid milk in Central America function for a better representation of the technology than the Cobb-Douglas function

\section{MATERIALS AND METHODS}

Monthly data from January 2006 to December 2015 were used to estimate demand and supply curves by two methods: OLS and TSLS. Nonetheless, monthly milk production and consumption data are not available for Costa Rica; instead annual data were collected from Euromonitor and then transformed into monthly data. In order to do so, we collected monthly data from BID/OEA (1973) which are the only available monthly estimates for Costa Rica. Then we calculated the average monthly share in order to determine seasonal patterns within a year.

Once the proportion of milk produced each month was obtained, we assumed this behavior would remain steady along the whole period of time of our research. In order to estimate this, annual differentials were distributed by month (equation 1):

$$
\text { Dif }=C y_{t+1}-C y_{t}
$$

Where $\mathrm{Cy}=$ yearly milk volume

According to BID/OEA`s (1973) data, a proportional monthly production was estimated and assumed to be steady trough time. This procedure was conducted using equation 2 :

$$
C_{m}=\frac{C y}{12}+\text { Dif } * \%
$$

Where \% stands for proportion of milk produced each month (estimated). Finally, our milk volume was obtained by a seven-month moving average in order smooth our increasing trend. Simple demand and supply OLS models

\section{DEMAND}

Several variables were tested to estimate demand: on a general perspective, demand is dependent on prices, income, and related products. We tested different variables as complimentary and substitute products, including coffee, tea and fruit juices. None of these were significant at 5\% level, even though several functional forms and structures were tested.

Milk prices were obtained from national retail prices.
Dairy products in Bangladesh

General perspectives on Free Trade Agreement on America

Dairy production On the other hand, as a proxy of income, the monthly index of economic activity (IMAE) was used; which estimates the relative monthly change in the volume of production of various industries (BCCR, 2018). The demand model was specified in equation 3:

$$
Q=\partial P_{m t-1}+I+\partial Q_{t-1}
$$

Where:

$\mathrm{Q}=7$-month moving average of milk production

$\partial P_{m t-1}=$ Log of lagged milk prices

$\mathrm{I}=$ Monthly economic activity index (as proxy for income)

$$
\partial Q_{t-1}=\text { Lag of } Q
$$




\section{SUPPLY}

In order to estimate supply, milk prices were used, as well as input prices since one of the most important variables for estimating supply is input prices. In this case, feed corresponds to $49.9 \%$ of total milk production costs according to The Costa Rican Milk Chamber`s estimation (2013-2014). We have included the following inputs which stand for our input index (equation 4). Weights were given according to animal feed needs adapted for the Costa Rican dairy sector (Sánchez, 2014).

$p_{s}=$ Sugar prices as a proxy for molasses: $3 \%$

$p_{v}=$ VAPFEED prices: $50 \%$

$p_{z}=$ International maize prices: $46 \%$

$p_{u}=$ International urea prices: $0.07 \%$

Therefore:

$$
\mathrm{n}_{\mathrm{i}}=0.03 * \mathrm{p}_{\mathrm{s}}+0.5 p_{v}+0.46 p_{z}+\square 0.07 p_{u}
$$

Sugar, maize and urea prices were obtained from Index Mundi data sets and VAPFEED prices were obtained from the Costa Rican Milk Chamber. This index was tested, however we decided to include only maize international prices as our variable for input prices. Other variables such as technology and transportation costs were tested but were not significant. Equation (5) depicts our supply function.

$$
Q=\partial P_{m t-1}+\partial P a
$$

Where:

$$
\begin{aligned}
& Q=7-\text { month moving average of milk production } \\
& \partial P_{m t-1}=\text { Log of lagged milk prices } \\
& \partial P a=\text { Log of lagged milk prices }
\end{aligned}
$$

\section{SIMULTANEOUS EQUATIONS}

Simultaneous equations were considered for analysis due to the existence of reciprocal relationships between economics variables, such as price and quantity that determine demand and supply. This kind of model uses endogenous and instrument variables. In this case, we followed two stages least square (TSLS) methodology in which price and quantity are both endogenous variables and on the other hand, IMAE and international maize price were considered instruments, which main function is to identify the slope of each curve. The following equation system depicts the functional form used to estimate demand and supply curves through TSLS.

$$
\begin{gathered}
Q=\partial P_{m t}+\partial I+\varepsilon \\
Q=\partial P_{m t}+\partial P_{m a}+\varepsilon
\end{gathered}
$$

Where:

$Q=7$-month moving average of milk production

$\partial P_{m t}=$ Log of milk price

$\partial I=\log$ of IMAE index

$\partial P m a=$ Log of international maize price $\square$

$\varepsilon=$ Error term

As can be observed, equation (6), uses the price of milk as endogenous predictor and IMAE as an independent variable and instrument. Similarly, equation (7), takes into account price as endogenous variable but international maize price as an instrument.

\section{RESUTLS AND DISCUSSION}

\section{Simple demand and supply OLS models}

\section{Demand}

Several functional forms were tested and the following model provided the best fit for our data. According to Akaike's criterion $(-1285,184)$ with a $\mathrm{R}^{\wedge} 2=0.998$ and 119 observations, results from our demand function can be observed in table 2 .

Table 2. Costa Rican milk demand function from OLS 2006:2015.

\begin{tabular}{lccccc}
\hline & Coefficient & Std. Error & t-ratio & $p$-value & sig \\
\hline const & 0.449508 & 0.0117642 & 38.21 & $<0.0001$ & $* * *$ \\
$\partial P_{m t-1}$ & -0.00877386 & 0.000997512 & -8.796 & $<0.0001$ & $* * *$ \\
$\partial Q_{t-1}$ & 0.162915 & 0.00336876 & 48.36 & $<0.0001$ & $* * *$ \\
$I$ & 0.000105145 & $6.02653 \mathrm{e}-05$ & 1.745 & 0.0837 & $*$ \\
\hline
\end{tabular}

Tests for autocorrelation and heteroscedasticity were run. Although several tests and remedy procedures were conducted, this model provides the overall best fit in spite of having autocorrelation $(12$ order with $\mathrm{p}$-value $=\mathrm{P}(\mathrm{F}(12,103)$ $>24.8439)=3.66618 \mathrm{e}-25)$ and heteroscedasticity problems (Breusch-Pagan p-value $\mathrm{P}($ Chi-square $(3)>10.3452)=$ 0.015848).

Prices show an inverse relationship with consumption and income a direct positive relationship which is expected from a demand function. On the other hand, lagged quantities are the most important variable for demand estimation.

\section{SUPPLY}

As well as in the demand estimation, several functional forms were tested and the following model provided the best fit for our data, according to Akaike's criterion (445.6528.) with a $\mathrm{R}^{2}=0.944$ and 119 observations. This model was run 
and then corrected by heteroscedasticity, results are depicted in table 3, however, this model presents autocorrelation which could not be corrected.

Table 3. Costa Rican milk supply function from OLS 2006:2015.

\begin{tabular}{lccccc}
\hline & Coefficient & Std. Error & t-ratio & p-value & sig \\
\hline const & 0.264964 & 0.0165581 & 16.00 & $<0.0001$ & $* * *$ \\
& & & & & \\
$\partial P_{m t-1}$ & 0.0910224 & 0.00448749 & 20.28 & $<0.0001$ & $* * *$ \\
$\partial P a$ & -0.0177310 & 0.00292628 & -6.059 & $<0.0001$ & $* * *$
\end{tabular}

Input prices depict a negative relation with milk quantity which is expected by the model's structure; higher input prices mean less production. On the contrary, milk prices show a positive relationship.

Simultaneous Equations

Regarding demand estimation, all three parameters considered in this model show high significant values, with a $\mathrm{R}^{2}=0.93$. This model shows an Akaike criterion of -507.2143; which is the lowest value among all others functional forms tested. Table 4 shows the result for the demand function.

Table 4. Costa Rican milk demand function from TSLS 2006:2015

\begin{tabular}{lllll}
\hline & Coefficient & Std. Error & p-value & sig \\
\hline Const & -1.3679 & 0.1195 & $<0.0001$ & $* * *$ \\
$\partial P_{m t}$ & -0.0405 & 0.0106 & $<0.0001$ & $* * *$ \\
$\partial I$ & 0.3309 & 0.0259 & $<0.0001$ & $* * *$ \\
\hline
\end{tabular}

As expected, the parameter of milk prices shows a negative sign, in this sense, higher milk prices imply less quantity demanded. On the other hand, the IMAE's sign is positive, result which is in line with economic theory.

Regarding supply curve, table 4 shows that retail prices have a positive sign and international maize prices exhibit a negative sign, which is aligned with economic theory since maize is considered the main input for milk production; positive changes in international maize price will shift supply curve to the left and vice versa. In this case the predicted model shows a R2 $=0.80$ and an Akaike criterion of $-507,2143$. Coefficient values as wells as p-values for each independent variable can be observed in table 5 .

Table 5. Costa Rican milk supply function from TSLS 2006:2015

\begin{tabular}{ccccc}
\hline & Coefficient & Std. Error & p-value & sig \\
\hline Const & 0.3444 & 0.0239 & $<0.0001$ & $* * *$ \\
$\partial P_{m t}$ & 0.1206 & 0.0006 & $<0.0001$ & $* * *$ \\
$\partial P a$ & -0.0321 & 0.0044 & $<0.0001$ & $* * *$
\end{tabular}

Next, we have divided our results in two sections. The first one considers a comparison between the results showed by standard OLS and TSLS. The second one exhibits the effect on volume due to changes in prices, considering Costa Rican current milk prices and US national prices as proxy for imported milk prices.

In order to start the comparison between OLS and TSLS, table 6, summarizes the coefficient results of OLS and TSLS.

Table 6. OLS and TSLS demand coefficient comparison

\begin{tabular}{lll}
\hline & Coefficient OLS & Coefficient TSLS \\
\hline const & 0.4495 & -1.3679 \\
$\partial P_{m t-1}$ & -0.0088 & \\
$\partial P_{m t}$ & & -0.0405 \\
$\partial Q_{t-1}$ & 0.1629 & \\
$I$ & 0.0001 & $0.3309(\partial \mathrm{I})$ \\
\hline
\end{tabular}

Regarding price coefficients, the TSLS price coefficient is 4.66 times the OLS's. In the case of the last one, a lagged price, as well as a lagged quantity is used in order to partially avoid autocorrelation. However, this did not solve autocorrelation and consequently a sub estimated coefficient was obtained. In this sense, TSLS's coefficients take into account the endogeneity problem, therefore, more reliable coefficients are obtained using this method. Similarly, the IMAE's coefficient depict a big difference among methodologies; as mentioned before, due autocorrelation problems in OLS, TSLS coefficient represents a trustful result. According to our model if milk prices increase by $1 \%$ quantity demanded is going to decrease by 0,04 units on average. In the case of IMAE's variations, demand is going to increase in 0,33 units if IMAE increases by $1 \%$.

Regarding the supply curve, similar coefficients were obtained by OLS and TSLS, however, as in the case of the demand model, the supply equation obtained by OLS exhibits autocorrelation problems. In this sense TSLS coefficient are taken into account in order to understand how supply is going to behave against changes of milk price or international maize price. Table 7 shows the OLS and TSLS supply coefficients.

Table 7. OLS and TSLS supply coefficient comparison

\begin{tabular}{lll}
\hline & Coefficient OLS & Coefficient TSLS \\
\hline const & 0.264964 & 0.3444 \\
$\partial P_{m t-1}$ & 0.0910224 & \\
$\partial P_{m t}$ & & 0.1206 \\
$\partial P a$ & -0.0177310 & -0.0321 \\
\hline
\end{tabular}

In this case, if the price of milk increases by $1 \%$, the quantity supplied will increase in 0,12 units on average. Regarding the instrumental variable, international maize price, if there is an increase of $1 \%$ on maize prices, supply is going to fall by 0,03 units on average, which means that the supply curve is going to move leftward.

Although in the rest of Central America, demand exceeds supply (Huang and Durón-Benítez, 2015) in Costa Rica supply exceeds demand; import tariff reliefs for the country are 
expected to change market opportunities for actors along the supply chain, not only local but international trade partners who could benefit from easier access. On the other hand, since prices are expected to decrease, local consumers may access lower prices and national production would be expected to adjust to lower prices.

When comparing national milk retail prices, the US milk retail price for 2017 was $\$ 3.156 /$ gallon which is equivalent to $\$ 0.833 /$ liter while the Costa Rican milk retail price for 2017 was $\$ 1.33$ which is almost $60 \%$ higher. Then demand and supply equations were estimated under two scenarios:

- Assuming national prices remained the same for 2017, i.e no decrease in Cosa Rican prices due to the free trade agreement.

- Assuming the free trade agreement and tariff reduction will cause Costa Rican market to lower national prices to meet at least US national retail prices.

If national milk prices remain at $\$ 1.33 /$ liter, ceteris paribus, demand would be determined by equation (8):

$$
\begin{gathered}
\mathrm{Q}_{\mathrm{D}}=-1.3679-0.0405 * \ln (1.33)+0.3309 * \ln (119.59) \\
\mathrm{Q}_{\mathrm{D}}=0.2036
\end{gathered}
$$

Nonetheless, if prices were to be reduced to meet U.S milk prices, then demand would be determined by equation (9):

$\mathrm{Q}_{\mathrm{D}}=-1.3679-0.0405 * \ln (0.833)+0.3309 * \ln (119.59)$

$$
\mathrm{Q}_{\mathrm{D}}=0.2225
$$

On the other hand, if national milk prices remain at $\$ 1.33$ / liter, ceteris paribus, supply would be determined by equation (10):

$$
\begin{gathered}
\mathrm{Q}_{\mathrm{S}}=0.3444+0.1206 * \ln (1.33)-0.0321 * \ln (1.33) \\
Q_{S}=0.2182
\end{gathered}
$$

Nonetheless, if prices were to be reduced to meet U.S milk prices, then supply would be determined by equation (11):

$$
\begin{gathered}
Q_{S}=0.3444+0.1206 * \ln (0.833)-0.0321 * \ln (1.33) \\
Q_{S}=0.1617
\end{gathered}
$$

If prices were to decrease to meet US national prices, demand would increase $9 \%$ while supply would decrease $26 \%$, meaning two main aspects:

- Price decreases disincentives milk farmers to produce. In this case, if the Costa Rican milk supply chain structure remains the same, a proportion of farmers would need to search for new alternatives, especially the smaller ones which are more dependent on prices (Rodriguez and Montero 2016). In this scenario, the proportion of milk supply would be covered by milk dairy products imports which can compete at lower prices. In this sense, the supply chain structure can change and shift towards larger farmers who can compete at lower prices; therefore, the proportion of larger farmers would increase and can potentially compete with cheaper dairy products imported.

- Price decreases would increase demand, this result is expected and is aligned with Huang and Durón-Benítez (2015), who estimated price elasticity in Costa Rica for fluid milk imports (-1.428), meaning price decreases would increase imported milk consumption. Our demand curve estimation is specific for the Costa Rican market and therefore corresponds to national retail prices. We have also estimated the demand function according to US prices, assuming these would be the benchmark for imported milk, lowering national average prices.

If milk prices decrease, then demand will increase but national farmers are expected to produce less according to economic theory and empirically tested by our results. The abovementioned situation means there would be an increasing gap between national demand and supply.

This study corresponds to a first approach in order to have a better understanding on the impact of the DR-CAFTA would have on the Costa Rican economy. Since this is a first approach within the national context, we faced important limitations regarding data availability such as the lack of monthly prices for complementary and substitutes milk products as well as monthly production and consumption patterns; however, our fitted models show coefficients of determination above 0.8 .

Costa Rican supply and demand equations for fluid milk were estimated using OLS and TSLS. There is a clear difference between the obtained OLS and TSLS coefficient values, in which the first ones are usually sub estimated. Due to the lack of monthly production data, we transformed annual series into monthly ones, through the implementation of trend and seasonal index. This procedure caused autocorrelation problems which were not possible to fix, however all coefficients sings are aligned with economic theory. If, domestic prices are supposed to decrease due to increasing quantities of imported lower-priced milk, then national demand would increase ( $9 \%$ average) and national production is expected to decrease ( $26 \%$ average); gap which is supposed to be filled by USAs' milk imports. These results hold for 2017 data, assuming 0\% tariff, no transaction costs and constant share of exports within national production.

Further research is needed on a micro level to understand the behavior of different actors along the milk supply chain since our results are useful on a macro level but not on understanding farmers' reaction towards the DR-CAFTA; we have only included an analysis based on milk prices changes. However, even if prices are certainly one of the most important variables in most industries, there are other factors which should be analyzed such as capital, labor and wages, transaction costs, land use and structural changes of the supply chain.

\section{REFERENCES}

Akoy, M. (2004). The Evolution of Agricultural Trade Flows"in M.A. Aksoy and J.C. Beghin (eds). Washington D.C: World Bank. 
Aksoy, M., \& Ng, F. (2010). The Evolution of Agricultural Trade Flow. World Bank.

Davis, C., Blayney, D., \& J. Cooper, S. (2009). An Analysis of Demand Elasticities for Fluid Milk Products in the U.S. International Association of Agricultural Economists Meeting, Beijing, China.

FAO. (2016, August 18). Food Balances: Livestock and fish primary. Retrieved from FAOSTAT: http://faostat3.fao.org/browse/ $\mathrm{FB} / \mathrm{BL} / \mathrm{E}$

Feenstra, R., \& Taylor, A. (2008). International Trade. New York: Worth Publisher.

Hannan, M., Dutta, A., Kabir, H., \& Hannan, M. (2010). Household demans for dairy products in Bangladesh: An Application of AIDS Model. J. Bangladesh Agril. Univ., 8(1): 121-126.

Hertel, T. (1999). Applied General Equilibrium Analyis od Agricultural and Resource Policies. Staff Paper 99-2.

Hinojosa-Ojeda, R., Lewis, J., \& Robinson, S. (1995). Regional Integrations Options for Central America and the Carribean after NAFTA. North American Journal of Economics and Finance, 6(2): 121-148.

Hoekman, B., Francis, N., \& Marcelo, O. (2004). Agricultural Tariffs or Subsidies: Which Are More Important for Developing Economies? The Wold Bank Economics Review, 18(2), 175-204.

Holzworth, D., Meinke, H., p.DeVoil, Wegener, M., Huth, N., Hammer, G., . . . Murphy, C. (2007). The development of a farming systems model (APSIM) - a disciplines approach. Retrieved from www.iemss.org/iemss2006/papers/w4/Holzworth.pdf

Huang, W., \& Durón-Benítez, A. (2015). Analysis of Demand for Dairy Product in Central American Countries under the CAFTA. Microeconomics and Macroeconomics, 3(1):7-14.

Kaldor, N. (1940). A Note on Tariffs and the Terms of Trade. Economica, XII (28), 377-380.

Lewis, J., Robinson, S., \& Wang, Z. (1995). Beyond the Uruguay Round: the Implications od an Asian Free Trade Area. China Economic Review, 6(1): 35-90.

Mukherjee, D., Bravo-Ureta, B., \& De-Vries, A. (2012). Dairy productivity and climatic conditions:econometric evidence from South-eastern United States. The Australian Journal of Agricultural and Resource Economics, 57: 123-140.

Muluwork-Atsbeha, D., D.Kristofersson, \& Rickersten, K. (2016). Component supply response in dairy production. European Review of Agricultural Economics, 43(2): 193-215.

Oprunenco, A. (2011). The Impact of the Russian Wine Embargo: Estimation of the Economic Impact. Expert Grup. Policy Association for an Open Society.

Ramirez Jaspeado, R., García-Salazar, J., Mora-Flores, J., \& García-Mata, R. (2010). Effects of the North American Free

Trade Agreement on milk production in Mexico. Universidad y Ciencia, 26(3): 283-292.

Rodriguez, V., \& Montero, M. (2016). COSTA RICAN MEAT

VALUE CHAIN DESCRIPTION: PRICE TRANSMISSION

AS A TOOL. International Journal of Food and Agricultural Economics, 91-101.

Shepherd, B. (2006). Estimating price elasticities od supply for cotton: a structural time-series approach. FAO Commodity and Trade Policy Research Working Paper N.21.

Zhu, X., Milán-Demeter, R., \& Lansink, A. (2012). Thechnical efficenci and productivity differentials of dairy farms on three EU countries: the role of CAP subsidies. Agricultural Economics Review, 130 (1): 66-92.

\section{Others (magazines and proceedings)}

Euromonitor. (2015). Country Report: Dairy in Costa Rica.

Euromonitor. (2018). Other Dairy in Costa Rica Report.
INEC. (2014). Censo Agropecuario. Retrieved from Actividades pecuarias. Total de fincas con ganado vacuno hembra para doble propósito por cantidad de animales y edad, según provincia y tamaño de la finca en hectáreas: http://www.inec.go.cr/agropecuario.

INEC. (2014). Censo Agropecuario . Retrieved from Actividades pecuarias. Total de fincas con ganado vacuno hembra para leche por cantidad de animales y edad, según provincia y tamaño de la finca en hectáreas: http://www.inec.go.cr/agropecuario.

OECD/FAO. (2016). OECD-FAO Agricultural Outlook 20162025. OECD Publishing, Paris, http://www.oecd-ilibrary.org/ agriculture-and-food/oecd-fao-agricultural-outlook-2016 agr outlook-2016-en.

Proleche. (2013). Situación Actual y Perspectivas del Sector Lácteo Costarricense. Visión de la Cámara Nacional de Productores de Leche. San Carlos, Costa Rica: http://www.proleche. com/recursos/documentos/congreso2013/Situacion_actual_y_perspectivas_del_sector_lacteo_a_nivel_nacional Vision_de la Camara_Lic_Jorge_Manuel_Gonzalez_Echeverria_Costa_- Rica-pdf. Retrieved from http://www.proleche.com/recursos/documentos/ congreso2013/Situacion_actual_y_perspectivas_del sector lacteo_a_nivel_nacional_Vision_de_la_Camara_Lic_Jorge_-Manuel_Gonzälez_Echeverria_Costa_Rica.p̄df

Quirós, M. (2013, March 13). Costa Rica y Nicaragua son los reyes de la producción lactea. MyT, ?

TICA. (2015). Ministerio de Hacienda. Costa Rica. Retrieved 10 12, 2016, from https://www.hacienda.go.cr/tica/web/honduncm1. aspx

World Economic Forum. (2016). Global Competitiveness Index. Retrieved 10 12, 2016, from http://reports.weforum.org/globalcompetitiveness-report-2015-2016/economies/\#economy=USA 
